\title{
Women's Resistance towards the Patriarchal Culture System in Geni Jora Novel by Abidah EL Khalieqy and Jalan Bandungan by NH.Dini
}

\author{
Rinche Wahyuli Martha, Yasnur Asri, Yenni Hayati \\ Universitas Negeri Padang \\ rinchewahyulimartha@gmail.com
}

\begin{abstract}
The patriarchal culture system that has rooted in Indonesia makes the women marginalized in every aspect of life. Women in Indonesia have long resisted the patriarchal culture. The resistance of women is reflected in literature. The purpose of this study was to describe the forms of women's resistance to the patriarchal culture in the novel system Geni Jora by Abidah El Khalieqy and Jalan Bandungan by NH. Dini. This research data were in the form of sentences, dialogue, monologue, and the expose of the narrator the stating the female forms of resistance against the patriarchal culture systems in both the novel. Based on the analysis of data, the opposition can be seen in various forms, among them the struggle for equal rights in the field of education, fighting for equal rights in the economic field, fighting for freedom of doing things or issuing opinions that are considered taboo by women, and fighting for freedom to make choices.
\end{abstract}

Keywords-feminism; patriarchy; female resistance

\section{INTRODUCTION}

Outwardly, women and men are different. However, both have similarities, namely gifted intellect and desire to actualize. Based on these, women who have a desire to show their actualization should have the same place and opportunity as men. However, in different parts of the world, women are still positioned to be under men. In fact, these differences of discrimination against women have been handed down through generations by their own immediate family.

Meanwhile, the women's resistance movement in Indonesia began to be seen since the 19th century. Mustikawati (2015, p. 66) explains that Kartini's struggle began to surface after Mr. JH Abendanon publishes Kartini letters with the title Door Duisternis Tot Licht in 1911. The book became popular when Armin Pane, the poet of Balai Pustaka, translated it and gave it the title Habis Gelap Terbitlah Terang. The book which later became the motto of Kartini became an inspiration for Indonesian women to fight for their position to be equal with men. This women's resistance is better known as "women's emancipation".

The problems that occur in women's lives have been a source of inspiration for women authors, even men, to create a work that represents the reality of a woman's daily life. The position of women who are considered second class citizens is a clear proof that since time immemorial women have always been positioned under men. Various problems of this woman poured the author in the literary works. Most women in literary works are presented as inferior figures.

Various aspirations of this woman one of them found in the literary works. Literary works born in the society of its creators are expected not only as entertainment, but literary works are expected to provide valuable lessons on the issues of life. In this case, literature is a form and the result of creative work that the object of human and life by using language as its medium (Semi, 1988).

Literary work is born because, of basic impulses that are in accordance with the nature of one's human being as a human being. Human nature as human beings is the human desire to express themselves, put interest and reality in life, and in an imaginary world that is thought of as the real world. In line with this human nature, the world of literature which is the work of the author is full of the realities of life. This is because the author in creating his work rests on a different world. On the one hand rests on the world of art, while on the other hand rests on the world of science. Literature as an art can be enjoyed as a world of science, literature can be researched and described. The science of literature examines the properties contained in literary texts, and how the text functions in society (Aminuddin 2013).

In today's modern era, literature increasingly has relevance in society. Literature does not only provide an the inner pleasure and satisfaction but also as a means of conveying moral messages to the community for social reality. Literary work is created in a certain period of time so that it can be a driver of the circumstances and situations that occur during the creation of literary works. Literary work can also be said to be a social document. This is because literary works emerge from the community and describe the situation and conditions in a certain period of time (Wellek and Warren 2014). 
Literary works are one of the cultural products that voiced women's rights. Its presence can inform readers about the forms of women's resistance to a binding cultural system. Turaeni (2010, p.257) argues that the existence of women in literature is also a manifestation of a "hidden" motto in a woman about the real state of her involvement in the construction of a society. In Indonesian literary works, women tend to be presented with a set of sentimental and heartfelt sentimental values, women have always been a defended and attention figure. Even in more literary works, women are portrayed as very submissive, obedient to parental decisions and not free to vote for husbands. If the women have already married, they usually serve the husband to a very loyal although not happy. The end of the story, they are powerless to face the situation until finally died.

Faced with a work of fiction, basically, we are faced with a world, a fictitious world, a world that is already equipped with its inhabitants and its problems. The world that is encountered in works of fiction can be of any world, such as the animal world, politics, science, education, that is the world of women's lives (Hayati, 2012, p. 85).

As the era of science and technology grew, Indonesian writers experienced various shifts, especially on the theme of the work. Back when emerging female authors like NH. Dini, Abidah El Khaleqy, Ayu Utami, and others. In writing the women's story, the author presents themes relating to public issues such as intellectual matters concerning philosophy, political issues, sexuality, and economics that were previously taboo for them. These authors have a social sensitivity in viewing the reality of society and are able to explore these issues implicitly or explicitly. The figures of women in their works are described as a figure of the independent character, insightful, and have the opportunity to choose from several options. The women told in the works are women who are trying to be independent and independent. The female characters created by the author appear to be more than a "female man" and a "concept" of how to become an advanced woman (Djajanegara, 2000: xii).

Some modern Indonesian novels that tell about the resistance of women in the patriarchal cultural system that shackles are Jalan Bandungan by NH. Dini and Geni Jora by Abidah El Khalieqy. The women's resistance to the patriarchal culture of the two novels has inspired Indonesian women to be free from the culture of their boundaries. In addition, various ways of making that resistance can also be a reference to fighters of feminism in Indonesia. This is the basis of the author to analyze the problems of some novels as the basis for preparing the thesis of women's resistance to patriarchal culture in the novel.

The novel is a work of fiction that tells of events broadly and complexly with reality as its reference. In the novel, some issues and problems are expressed by the author with certain circumstances. According to Semi (1988), the novel reveals a concentration of life at a time of tension and a firm problem. The novel presents human and humanity issues with color because of the imaginary author's expertise.

Novels can express things freely, present something more, in more detail, more detail and involve more complex problems. Meanwhile, Atmazaki (2007) explained that novels express something about human experience. The problem contained in the novel is taken from the patterns of life known to humans, or a set of life in an imaginative time and place.

According to Muhardi and Hasanuddin WS., (2006), fiction has constructive elements from within fiction itself (intrinsic elements) and elements that influence the creation of fiction from the outside (extrinsic elements). The intrinsic element is divided into two kinds, namely the main elements and supporting elements. The main element is all that is related to the giving of meaning that is poured through the language, while the supporting element is everything used in utilizing the language. The main fictional extrinsic element is the author, while other influences will enter fiction through the author.

In fiction, there are various problems in public life, one of which is patriarchal culture. Discriminatory behavior and patriarchal culture in society have virtually marginalized women almost in all the riches of life. The patriarchal culture places men as the primary focus thus creating an unequal power relationship between men and women (Guamarawati, 2009, p 46). In that relationship, men are considered stronger parties to learn to control and control women, so women are seen as the object of men and ultimately make women regarded as weak creatures. This is what makes women fight against patriarchal cultural discrimination faced so far.

Wiyatmi (2010, p.40) states that feminist literary criticism is one of literary criticism (literary studies) based on feminist thinking which desires justice in looking at women's existence, both as a writer and in her literary works. Feminist literary criticism began with the feminist's desire to examine the works of women's writers in the past and to show women's image in the work of male authors who present women as creatures who are in various ways suppressed, misinterpreted and underestimated by the dominant patriarchal tradition (Djajanegara, 2000). Both desires create a variety of ways of criticism that sometimes coalesce. For example, in examining women's images in women's literary works, attention is focused on ways that express the pressures that female characters face. Because it absorbs patriarchal values, it is possible that a female writer creates female characters with stereotypes that meet the requirements of the pastoral society. In contrast, women's studies in male writings may show strong female characters and may, in fact, support feminist values.

A feminism approach is an approach to literary work with a focus on gender equality that is unequal and promotes on a balanced level between men and women (Djajanegara, 2000). Feminism is not a women's rebellion 
against men, an attempt to combat social institutions, such as domestic institutions and marriage or the view of women's efforts to deny their nature, but rather as an attempt to end women's oppression and exploitation (Fakih, 2006) Feminism arises from the prejudice of gender that subordinates women.

Specifically, this study aims to describe the form of women's resistance to the patriarchal culture system in Geni Jora 's novel by Abidah El Khalieqy and Jalan Bandungan by NH. Dini. The results of this study are expected to provide benefits to the readers, especially students, lecturers, and researchers, as one means of studying the discrimination experienced by women in a patriarchal society. In addition, this research is expected to contribute to feminism research in Indonesia.

\section{METHODS}

Researched conducted on two novels, namely Geni Jora by Abidah El Khalieqy and Jalan Bandungan by NH. Dini type of content analysis research (content analysis). This study aimed to explored the contents of the messages contained in the object of researched. This research used qualitative methoded which exposes data in scientific logic, not in the form of a number, amount, and percentage for easy understood and concluded.

The data of this research were sentences, dialogues, and monologues that express women's resistance to the patriarchal cultural system in the novel Geni Jora and Jalan Bandungan. The source of this researched data was Geni Jora 's novel by Abidah El Khalieqy, published in 2004 by Matahari, and Jalan Bandungan by NH. Dini, which was published in 2009 by Gramedia Pustaka Utama.

\section{FINDING AND DISCUSSION}

There have been many studies of women's resistance, one example being Yasnur Asri's research, "Women's Struggle toward Gender Unfair: A Case Study in Indonesian Novel”. According to Stuares (in Asri, 2014, p.192), there are four prototype classes of women uneducated as men: (1) poor women, (2) middle-class women, (3) Muslim women, and (4) noble lady. The first prototype class of poor women did not get any education at all. Women in this class usually work in agriculture and they are only allowed to learn sewing. Women in second-class prototypes (middle-class women) are also not allowed to go to school even though they can afford to pay for it. They usually marry at the age of 12-15 years. After marriage, they usually help their husbands to work in the fields or sell some vegetables. They get treated well by their husbands because, in fact, they are able to earn money for themselves. Muslim women get a religious education at home and usually marry at the age of 15 years.

Discriminatory behavior in patriarchal culture has markedly marginalized women almost in all the niches of life. The patriarchal culture places men as the primary focus thus creating an unequal power relationship between men and women (Guamarawati, 2009, p 46). In that relationship, men are considered stronger parties learn to control and control women, so women are seen as the object of men and ultimately make women regarded as weak creatures. This is what makes women fight against patriarchal cultural discrimination faced so far.

The opposition can be seen in various forms, among them the struggle for equal rights in the field of education, fighting for equal rights in the economic field, fighting for freedom of doing things or issuing opinions that are considered taboo by women, and fighting for freedom to make choices.

In Jora's story on the novel Geni Jora and the story of Muryati in novel Jalan Bandungan, all aspects of this form of female resistance are found. This is evidenced by the depiction of the main character of women who make various efforts to free from patriarchal cultures that shackles.

\section{The Resistance in Education}

Novel Geni Jora and Jalan Bandungan have the similarity of raising the importance of education issues. Both of these novels show that to pursue a woman's education must deal with two things, namely the tradition of people who still run the patriarchal system and the difference in treatment of men and women students. Patriarchy is a system of relationships between sexes based on patriarchal law. Walby (1989) explains that patriarchy is a system of social structure, a practice that places men in the dominant, oppressive, and the exploiting position of women.

The picture the difference in the education of girls and boys is seen in the Geni Jora novel. A Jora's figure who is a smart girl should always be discriminated by his grandmother who thinks women should always be under men.

At that time I was nine years old, sitting in the fifth grade of elementary school. My grandmother had cut the wound in my heart. And the wound kept gaping, every time. My grandmother's physics continues to evolve, but her mind has never evolved. He still sat him in his chair with his commandments, while I will continue to run in the future. Though often struck by his evil mouth, basically, my soul and spirit inherited my father's adventures. That is why, my position continues always at the forefront and my rankings continue to survive, even though my grandmother is always blocking (GJ, 2004, p. 62).

The above quotation indicates that obtaining an education is one form of women's resistance to the patriarchal cultural system. In the above quotation, it appears that Jora is trying to continue to pursue education and strive to be the 
best, even though from childhood always under patriarchal pressure. Jora grew up in a very patriarchal family and always downgraded women's abilities. He never gives up hope and keeps fighting to prove to his grandmother that women can excel like men. All discrimination received from his grandmother from childhood, made Jora as a whip to continue the spirit of being an educated woman.

Nadia Masid, like Nishwa or Qadisha, is a generation of today who has enjoyed technological progress. Go to college and go abroad to conferences. She is no longer a woman with her hands clasped with flour mixed with tajin and kuskus. Nor the woman with jellaba weaving a basket of dirty clothes going to the Onilariver. Nasia Masid is a prototype of educated women who bring a distinctive tendency of women born in South Morocco (GJ p.13).

The above quote shows the form of Jora resistance who wants to become an educated, now-educated woman. Jora struggled to continue her education, even abroad. He does not want to be a woman who only becomes a housewife, taking care of the house all day, without having a social life and cannot actualize himself. For her, today's women are not only living dirty in the kitchen but can also be speakers at various prestigious seminars.

The description of the form of women's resistance to education against patriarchal culture is also found in the novel of Jalan Bandungan. Below is a quote that shows it.

Meanwhile, I want to enjoy my solitude, which apparently also means my freedom to determine my attitude and actions. In the first year of my suffering, I was always supported and helped by my mother. Without in-laws, without brother-in-law, my mother is a source of strength in various forms. After the Wid's family noticed us, confidence in myself increased my immunity to cope with insinuations, ridicule, and insults. Both spoke openly in front of me and I heard people say behind my back. That conviction led me to re-enroll in the study while continuing to work. The Institute of Education in our city offers opportunities for elementary school teachers who want to increase their knowledge (JB, 2009, p. 134).

An above quotation is a form of women's resistance to the patriarchal cultural system marked by fighting for equal rights in the field of education. In the data which is the expression of figure I (Muryati), it appears that he proved to his environment that he can survive without the presence of a husband. He continued to work and continue his education as a teacher, regardless of the scorn he received. Various challenges and exams experienced since Widodo her husband jailed, making Muryati continue the education and work harder. He believes in education, his ability to teach can be better.

The fate of women is very heavy in the patriarchal society and there is often no strenuous effort to overcome this injustice of women. In fact, there are no institutions (customs) that validate this gender inequality, because the patriarchal culture actually takes place for generations. Religion itself is neutral, worship is done on totems that do not gender. One way to counter the dominance of this patriarchy is with education. Women who fight against patriarchy, continue to seek education as high-level. They consider education does not only belong to men. By having a college education and career, they can prove to the public that women can be equally superior to men.

\section{Resistance in Economic}

The economy is one of the most important things in life, especially home life. Many husbands restrict the material given to their wives, without realizing that the needs of the household and the needs of the wives should be different. One example of the form of women's resistance in the economic field is seen in the quotation in the novel of Jalan Bandungan below.

"What? Are you going to teach again? "Wid's voice was surprised to hear my decision.

"I'm tired of having to bicker first if it takes extra cost or that. If I work, even if my salary is small, but I do not need to beg "(JB p. 105).

The quote above is a conversation between Muryati and her husband Widodo. Wid forbade Muryati to teach because he felt that he had fulfilled his obligations as a husband. However, according to Muryati her husband rarely gives him money for their household needs, most of which give money to buy household purposes is his own mother. Muryati asks her husband to allow her to return to teach so that she can help her husband for their household needs, but Muryati's request is instead treated by her husband. According to her husband, the obligation of a wife is to take care of the house and her children. However, Muryati's own needs as a wife, he cannot meet, that's what makes Muryati very disappointed with her husband.

The next data showing the form of women's resistance to the patriarchal cultural system are found in the quotation below.

In my routine life as a housewife, gradually I became more established and knew how to suppress my feelings: I accepted my destiny. Financial difficulties as strong as my strongest ability was finally accepted by way of 
indifferent food that I served on the table. I learned to be stealthy towards my husband. The wages I received from Mother were no longer used as a buyer of anything to my husband. The kids and I ate the kind of dishes we liked. And my own money I bought the food. But for the dining table, it's different. One sentence or four sentences of my husband's reproach with regrets about the food service were not answered by any other explanation except "Everything is expensive now" (JB 148).

Based on the above quotation, it can be seen that Muryati's character's resistance to her husband never cared about enough or not the money he gave to fulfill family needs. The form of Muryati's resistance was marked by fighting for equal rights in the economic field. After having her own income, Muryati was able to meet the needs of her children but to eat her husband she still gave food soberly, so that her husband realized that the money provided was not enough for family needs. Women who experience domestic violence, including economic violence, often do not have the strength to fight (Sugihastuti, et al, 2010). By doing this, Muryati shows that a wife cannot just surrender under the power of a man.

Based on the above two quotations it appears that the man, the ruling party, will provide material protection to women and will apply a moral justification for his existence. Women who are accustomed to living without thinking about economic risks tend to enjoy this comfort. The real problem for women is that the material provided by the husband cannot meet the needs of the family. To help meet the needs of this family, women begin to show that they too can work like men.

Some women who still hold the ancient principle, have no freedom in determining their own destiny. He assumes that he belongs to her husband and her husband is the hope for him that will save him in the world to the Hereafter. But in reality, life does not all go as expected. Many husbands are just not trustworthy, dishonest, for example, in terms of income, many husbands who in earnings were not been able to meet the needs of the child and his wife. If this happens, the wife should not remain silent and surrender to fate. The wife must dare to get out of the ancient thinking and work to meet the needs of her family. He must work and have a career, and to support this course he must be educated and have the expertise in working.

The form of women's resistance in the economic field to free from this patriarchal culture is not found in the GeniJora novel. In the GeniJora novel, the main thing the author discussed is how Jora's struggle in education. Jora who came from a family rich enough never had problems in the economic field, especially in the story is told Jora not married.

\section{Resistance to Things that are deemed Taboo Done or Spoken by Women}

A woman living in a patriarchal society is destined to continue to live in a clean and tangible ordinance, which may have no other purpose, then a false pretense. He can only do what is considered inappropriate and inappropriate in a patriarchal society. But in Geni Jora novel is clear, how Jora dare to do things that are still considered taboo done by women. The right can be seen in the quotation below.

Maybe I should also learn to ride all the trees in the back garden, especially the higher ones. That way, I can watch all the events, all events, comedies or others out there, far out there. When I exposed my intentions to Lola, she supported one hundred percent. From that moment on, we found another ladder to freedom, that is by climbing a tree (GJ p 76).

The above quotation shows the form of women's resistance to the patriarchal cultural system marked by fighting for the freedom of doing things and issuing opinions that are considered taboo done or spoken by women. In the quotation it appears that female characters do things that women should not do with their families, that is climbing trees. Women here climb trees to see things happening outside their homes. He considered, by climbing a tree, he was a step towards women's freedom.

In line with the above data, there are some other data that also show the form of women's resistance which is marked by fighting for freedom to do things and issuing opinions that are considered taboo done or spoken by women. It can be seen in the data below:

"If for example Zakky polygamy, what is Jora's reaction," asked Najwa. "I will polyandry, use illegal ways." "Like what?"

"First I will khuluk him. Then marry again with a movie star that handsome than Zakky. Polyandry or not, what matters is fairness. Equally two "(GJ p. 169-170)

In the above data shows that the female character of this novel, Jora, tries to tell others that he is unwilling to be polygamous. If her husband did polygamy, then he will respond by also doing polyandry. Polyandry itself is considered taboo by women.

History shows us that men always maintain their power. Since the beginning of the era of patrilineal society, they have thought to maintain that women are always dependent on them. Laws and regulations are created in such a 
way that women are truly distinguished as "Other Persons" (Beauvoir, 2006). Children must comply with the pressure of their families, the wife must obey her husband, so women do not have the initiative to make their own choices.

Women today are in the process of restoring feminist myths. They begin to express their freedom in blatant ways, but unfortunately, they are not, or have not been able to enjoy the life they want as men do. Wherever they go, the finish line always manifests itself as inappropriate worth of the things they do, which means tantamount to recognizing male dominance. A woman in patriarchal domination is required to continue living in a clean and real ordinance, which may have no other purpose than a false pride. He only knows abstract freedom from within because it is in every non-free way, he refuses to accept the principles and values that curb him.

Women who take the fight, start doing things that women should not do in the neighborhood, or something taboo. They feel there is no limit between what men and women can do. The various things that women do is a tangible form of their opposition to the patriarchal cultural system that curbs it. They do not care about the impropriety that people say, because they just do the things they like and think they're right.

The resistance to freedom from what is considered taboo done by women is not found in the novel of Jalan Bandungan. The author of the novel of Jalan Bandungan is more concerned about how married women can be free from patriarchy by prioritizing education.

\section{Resistance for Free Determining Choice}

Women are regarded as weak creatures that have no opinion of their own. This is what makes in various aspects, women always have to follow what is chosen by the husband or his family. In the novel Geni Jora and Jalan Bandungan, female characters here have the will to be free to make their choice. This can be seen in the quotation below.

I think the time has come for me to take firmness about this unexplained multiplicity of this cross lane. I want to be more free to move and speak in my career and in acting as an intellectual female citizen. (JB, p.302).

An above quotation is a form of women's resistance to a patriarchal cultural system characterized by freedom of choice. Years of independent living when her husband was imprisoned did not make Muryati completely free. The system in society keeps it tied under the male rule. Whatever he does, he still has to get formal approval from her imprisoned husband. After years of living alone, but not the widow, Muryati finally ventured to divorce officially. Officially widowed, he can determine his own life without the permission of her husband.

Marriage is a traditional destiny given to women by society. It is true that most married women, once married, plan to marry and suffer from being unmarried. Marriage is always different when viewed from the point of view of men and women. These two sexes need each other, but their needs never bring about mutual conditions among themselves. If a woman is married, she is fully bound under the husband's control. Although the husband leaves her without giving her status clarity, she still cannot escape from the male power. The system of government to form everything that women want to do must be permitted by the husband/man. This is what makes a woman want to be free to choose her life choice, whether she wants to remain with the status of a wife but without a husband, or choose to become a widow.

The next data showing the form of women's resistance to the patriarchal cultural system can be seen in the quotation below.

"Do you know what the world belongs to both of us? That means, half the power of men and half belong to women.

You can call Lola and date her as I would call Azzav and fondle her" (GJ p.169-170).

The quotation above shows the form of women's resistance by making their own choices. Jora is a woman who has strong principles in her life. For him, what men do, can also be done by women. If his partner cheated, Jora can cheat. With the principle of equality embraced by Jora, then he will never be considered low by his partner.

The next data which is also a form of women's resistance to fighting for freedom of choice can be seen in the quotation below.

Zakky is funny. I stressed to him one more thing if he still wanted to be with me and later make me his companion, he had to start learning to be a faithful man on one choice. Believers are monogamous. Do not like to flirt and seduce women. Or he will lose me forever (GJ p. 207).

The quote above shows the Jora principle that does not want to be united or polygamous. The experience of living in a polygamous family taught Jora that being polygamous is not fun. Based on that experience, Jora applies to her future husband that she will never want to be polygamous and if one day her husband cheats on or polygamy, then Jora will leave her.

Based on the data above shows that women can determine his own life choice if he wants and dare to take the fight. Resistance in the form of how the spirit of women to have a better education, better economic life, free to do 
things that had been considered taboo, and free to make choices. What is interesting from the two novels reviewed is that women's resistance has been seen by the authors of the 80s. Jalan Bandungan, which was first published in 1989 , has shown how the form of women's resistance to the patriarchal cultural system. Meanwhile, in Geni Jora's novel published in 2004, the form of women's resistance looks more modern and brave.

This proves that the patriarchal cultural stranglehold of Indonesian women has made the writers intrigued to criticize these issues in the form of literary works. The patriarchal culture that is already deeply rooted in Indonesian society makes the author pour his criticism in the form of a novel that raises the idea of the importance of education for women, how women should be equal in economics, free to do what is considered taboo, and free to make choices they desire. With this expected, there is no longer a patriarchal culture that curbs the freedom of women.

\section{CONCLUSION}

Based on the discussion, it can be concluded that the forms of women's resistance to the system of patriarchal culture in Geni Jora novel by Abidah El Khalieqy and Jalan Bandungan by NH. Dini leads to four main things, namely the opposition of equal rights in education, equality of rights in the economy, opposition to what is considered taboo done or spoken by women, and free resistance to make choices.

Jora's opposition in the Geni Jora novel shows more modern women's resistance forms that want to have better education and be equal to men. While the resistance made by the character Muryati in novel Jalan Bandungan prioritizes how he is equally in the economy and free to make choices because he has long lived in the domination of her husband.

\section{References}

Aminuddin. (2013). Pengantara apresiasi sastra. Bandung: Sinar Baru.

Asri, Y. (2014). Women's struggle toward gender unfair: a case study in Indonesian novel. Linguistics and literature studies, 2 (7), 190-197.

Atmazaki. (2007). Ilmu sastra: teori dan terapan. Padang: Universitas Negeri Padang Press.

Beauvoir, S.D. (2006). The second sex: kehidupan perempuan (terj). Surabaya: Pustaka Promothea.

Dini, NH. (2009). Jalan bandungan. Jakarta: Kompas Gramedia.

Djajanegara, S. (2000). Kritik sastra feminis sebuah pengantar. Jakarta: Gramedia Pustaka Utama.

Fakih, M. (2006). Analisis gender \& transformasi sosial. Yogyakarta: Pustaka Pelajar.

Guamarawati, N.A. (2009). Suatu kajian kriminologis mengenai kekerasan terhadap perempuan dalam relasi pacaran heteroseksual. Jurnal kriminologi Indonesia. 5(1). 43-55.

Hayati, Y. (2012). Dunia perempuan dalam karya sastra perempuan Indonesia. Humanus. Vol XI (1). 85-93

Khalieqy, A.E. (2004). Geni jora. Yogyakarta: Matahari.

Muhardi dan Hasanuddin WS. (2006). Prosedur analisis fiksi: kajian strukturalisme. Padang: Yayasan Citra Budaya Indonesia.

Mustikawati, C. (2015). Pemahaman emansipasi wanita: studi hermeneutika makna emansipasi wanita dalam pemikiran RA. Kartini pada buku habis gelap terbitlah terang. Jurnal kajian komunikasi. 3 (1). 65-70

Ruthven, K.K. (1985). Feminist literature studies: an introduction. Melbourne: Cambridge University Press.

Semi, M.A. (1988). Anatomi sastra. Padang: Angkasa Jaya.

Sugihastuti \& Itsna H.S. (2010). Gender dan inferioritas perempuan. Yogyakarta: Pustaka Pelajar

Turaeni, N.N.T. (2010). Resistensi perempuan multikultural dalam novel seroja karya Sunaryo Basuki:kajian feminis. Subbidang Pengkajian Sastra Balai Pustaka Surabaya. 257-264.

Walby, S. (1989). Theorizing patriarchy. Oxford:Blackwell.

Wellek, R. \& Waren, A. (2014). Teori kesusastraan (terj. Melani Budianta). Jakarta: Gramedia.

Wiyatmi. (2010). Citraan perlawanan simbolis terhadap hegemoni patriarki melalui pendidikan dan peran perempuan di arena publik dalam novel-novel Indonesia. Atavisme. 12 (2). 137-217. 